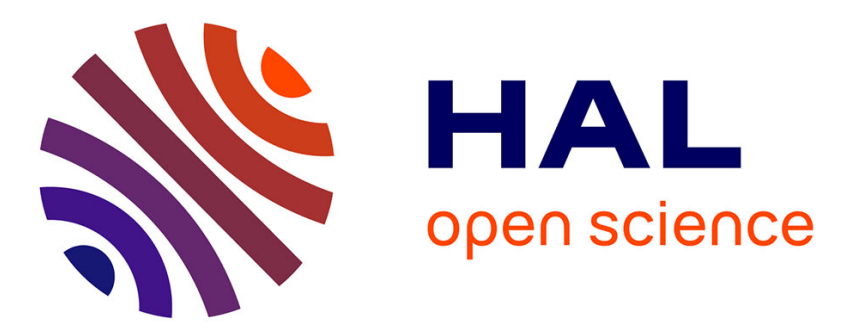

\title{
A Century of Archaeological Heritage Protection and Exhibition in China
}

Zhao Huijun, Luc Doyon

\section{To cite this version:}

Zhao Huijun, Luc Doyon. A Century of Archaeological Heritage Protection and Exhibition in China. The Historic Environment: Policy \& Practice, 2021, 12 (2), pp.146-163. 10.1080/17567505.2020.1836931 . hal-03358379

\section{HAL Id: hal-03358379 \\ https://hal.science/hal-03358379}

Submitted on 22 Feb 2022

HAL is a multi-disciplinary open access archive for the deposit and dissemination of scientific research documents, whether they are published or not. The documents may come from teaching and research institutions in France or abroad, or from public or private research centers.
L'archive ouverte pluridisciplinaire HAL, est destinée au dépôt et à la diffusion de documents scientifiques de niveau recherche, publiés ou non, émanant des établissements d'enseignement et de recherche français ou étrangers, des laboratoires publics ou privés. 


\title{
A Century of Archaeological Heritage Protection and Exhibition in China
}

\author{
Zhao Huijun and Luc Doyon ${ }^{\mathrm{a}, \mathrm{b}}$

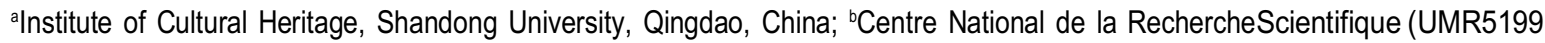 \\ PACEA), Université de Bordeaux, Pessac CEDEX, France \\ CONTACT Zhao Huijun ttxsyt@126.com
}

\begin{abstract}
Over a century ago, in order to curb the looting and trafficking of archaeological relics and alongside the development of modernarchaeological excavation protocols in the region, China introduceda legal framework to protect its archaeological heritage. Over the years, the concept of heritage protection and exhibition has undergone three major developments closely intertwined with the country's political and social contexts. The present review summarises the processes at the root of this specific trajectory. Following the introduction of a clear statement of ownership by the Chinese government in the 1920s, Historical Museums became the safe keepers of archaeological relics, therefore removing this heritage type from the private sphere and putting it in the public realm. Deliberations on how to preserve the authenticity and integrity of archaeological heritage in 1950s encouraged the establishment of Archaeological Site Museums, an institution where both archaeological relics and sites can be protected and put on display. Since the $21^{\text {st }}$ century, fast urbanisation and an ever-growing market for tourism accelerated the construction and increased the popularity of Archaeological Site Parks, an urban setting combining both archaeological attractions and leisure activities. In this context, archaeological heritage has become a tool fit for touristic development and economic growth.
\end{abstract}

KEYWORDS

Tourism; heritage management; Museology; Historical Museum; Archaeological Site Museum;Archaeological Site Park

\section{Introduction}

Thirty years ago, during the $9^{\text {th }}$ General Assembly of the International Council on Monuments and Sites (ICOMOS) held in Lausanne, Switzerland, the International Committee for the Management of Archaeological Heritage proposed a Charter that defined the concept of 'archaeological heritage' and listed principles of global validityfor its management and protection. The first Article of the Charter for the Protection and Management of Archaeological Heritage defines this heritage type as 'all vestiges of human existence, [which] consists of places relating to all manifestations of human activity, abandoned structures, and remains of all kinds (including subterranean and underwater sites) together with all the portable cultural material associated with them' yielded through the application of archaeological methods. ${ }^{1}$ The ratification of this Charter and the adaptation of its core principles to existing legislations constitute a process worthy of investigation. Indeed, long-standing socio-cultural ideals and shifting political interests often play key roles in this development. To that regard, China constitutes an intriguing case study. Despite its long history of relics' curation, ${ }^{2}$ the implementation of an institutional system responsible for the protection and exhibition of archaeological heritage is a relatively recent phenomena in the Chinese cultural landscape. Considering that China is in the process of reconfiguring its heritage management policies in order to adapt to the pressing needs of a market economy, ${ }^{3}$ and given the special place archaeological heritage holds in the formulation of a national narrative, ${ }^{4}$ it is imperative to review the development of initiatives for the protection and exhibition of archaeological heritage and highlight the challenges they may face in the future.

At present, the definition and classification of 'archaeological heritage' in Chinese laws, regulations, and official documents are relatively, and purposefully, broad. Two main categories can be distinguished: archaeological remains and archaeological relics.Archaeological remains comprise both immovable cultural sites, such as cave sites, settlement sites, ancient city sites, ancient kilns, palaces, residential sites, temples, mining and smelting sites and ancient tombs including single tombs, mausoleums, cemetery or stone carvings. Nowadays, archaeological sites are commonly understood as being part ofthis category. Archaeological relics, on the other hand, refer to movable items of material culture found in the course of archaeological activities. 
They include utilitarian objects of all kinds, tools made of stone, bone, ceramic, porcelain, glass, ore, wood, textile, for example, as well as artworks and historical documents. Within each category, the discoveries are further divided into classes according to their 'value'. To this day, Chinese scholars have mainly focused on this process of categorising archaeological relics between valuable and ordinary classes, as well as on issues relating to the protection and management of archaeological heritage through research planning, policies andregulations. ${ }^{5}$ These themes are likewise recurrent in international and national meetings (e.g., the 'Universal Standards for Archaeological Heritage Management' during the ICAHM Annual Conference held in Jishou, China, in October 2014, or the 'Archaeological as a Social Resource: Protection and Utilization' conference hosted the same year byPeking University's School of Archaeology and Museology). Yet, questions related to how and why archaeological heritage protection and exhibition developed through the years to become a focal issue in China's domestic policies has received less attention.

The present paper reviews some of the major events that led to the current archaeological heritage management system in China. As a special form of heritage, archaeological heritage is not only the evidence of past human activities, but it also includes the modes of modern cultural production that can be visited and consumed through itsdisplay. In other words, the collection and curation of archaeological remains and relics constitute prerequisites for the protection of archaeological heritage, while its exhibition highlights the contemporary values attached to, and the significance emerging from, it in a broader social narrative. Based on literature review and fieldwork, three dominant modes of protection and exhibition can be identified in China: History Museums, Archaeological Site Museums and Archaeological Site Parks. They, respectively, emerged in the 1920s, 1950s, and at the beginning of the $21^{\text {st }}$ century. Their appearance in the Chinese cultural landscape was highly conditioned by a will to find common grounds between the social aspirations, academic imperatives and the legitimisation of domestic cultural policymakers through time, as well as the influence from Western countries. The emergence of the Site Museums and Parks represented an effort to overcome limitations inherent in the History Museums while responding to new standards established for dealing with archaeological heritage. Interestingly, the advent of a new modes did not result in the disappearance of the history Museum. Indeed, the three modes nowadays coexist and complement one another. Nonetheless, this system faces important pressuresto adapt to a fast-paced, shape-shifting, market economy where cultural consumption is ephemeral and instantaneous. We argue that understanding the development of archaeological heritage protection and exhibition in China over the last century is essential to ensure its future protection and to adapt its display in a context characterised by the commodification of cultural heritage.

\section{From Private to Public: Museums as Safe Keepers of Archaeological Heritage}

Traditionally, archaeological remains and relics are esteemed by the Chinese people who generally view them as bearing the 'soul of their ancestors'. ${ }^{6}$ As early as the Song dynasty, and again during the Qing dynasty, antiquarians at the service of the elite developed rigorous excavation, analytical, and cataloguing methods for unearthing and curating ancient relics, some of which were used thereafter in ceremonial state rituals. ${ }^{7}$ Regardless of the social origins of the deceased, it is customary to protect human remains andofferings by continuously piling earth and planting trees on burials, and erecting stone tablets to identify them. These buried relics were, and still are, intended for the ancestors' use in the other world and considered inviolable. This indigenous mode of relic protectioneffectively safeguarded many ancient sites and their content for thousands of years. Asa result of the densification of human settlements throughout the years, these valuable relics often ended up being found literally in the backyards of many Chinese citizens. ${ }^{8}$ At the beginning of the $20^{\text {th }}$ century, the ongoing fascination in Europe for rare oriental objects combined with the introduction of foreign excavation methods by European and Japanese archaeologists shed light on the richness of the Chinese archaeological record and triggered the emergence of a collective awareness of its value. Unsurprisingly, less scrupulous individuals sought to personal gain by selling the objects they had in their possession and/or pillaging archaeological sites and selling their finds to foreigners eager to obtain exotic Chinese cultural relics that were highly prized abroad. On some occasions,direct access to the archaeological sites was facilitated, 
which resulted in foreigners smuggling archaeological heritage out of China. The ease and profitability of these activities relied heavily on the absence of clear archaeological heritage managementregulations and an institutional structure responsible for protecting it.

The first attempt to legislate on the preservation of antiquities in China dates back to 1909 when the Qing court proposed its 'Promotion Measures of Ancient Antiquities Preservation'. This for the first time defined and categorised Chinese antiquities ina fashion similar to their Western counterparts. However, because of political turbulence at the time, the adoption and implementation of these measures at a national level faced setbacks that limited its effectiveness. Consequently, the Ministry of Internal Affairs of the Beiyang Government proposed the Interim Measures for the Preservation of Antiquities in October 1916. This temporary and emergency document listed the important cultural relics that required protection, i.e., imperial mausoleums and tombs of outstanding men, remains related to historical or modern celebrities, inscriptions and statues, trees of former countries, bronze relics, bamboo and wooden slips, paintings and calligraphies, etc. The aim of these Measures was two-fold: first, it listed the aspects of archaeological heritage that required to move from the private to the public domain; second, it constituted an effort to establish the Beiyang Government as the legitimate national governing body. Unfortunately, however, the categories of architectural and material culture included in the so-called 'important relics' selection were relatively limited in number considering the richness of the Chinese archaeological record. Furthermore, these Measures did not include provisions for the creation of a protection agency nor didthey supply national and local authorities with specific means or methods to enforcesuch protection. ${ }^{9}$ Finally, the Interim Measures were by definition 'temporary', they were never enacted into a proper law. Consequently, such legal norms were ineffective inprotecting archaeological heritage or to curbing illegal theft, trafficking in archaeological relics or clandestine excavation.

By the mid-1920s, formal archaeological excavations led by academicians were becoming more and more frequent in China. These early works played a crucial role in shedding light on the richness of the Chinese archaeological record despite the use of sampling andcuration methods that would nowadays be considered inadequate for the ideal preservation of both archaeological relics and remains. Nonetheless, the legal void left open by theBeiyang Government with regard to the protection of archaeological relics becamea source of concerns and tensions between the local and central governments in theearly years of the Nanjing decade. Two incidents played an important role in outlining thenext legal framework for the preservation of archaeological relics: the 'Shang Zhen appeal'in 1928, and the 'dispute over the relics of Yin Xu' in 1929. In the first year following his initial appointment as Chairman of the Hebei Province, Shang Zhen became increasingly concerned about the fate of Chinese archaeological relics. On the one hand, he felt that the looting and selling of antiquities in China was becoming a serious problem. On the other hand, he deplored the lack of control by the governments over the archaeological activities conducted in the Hebei Province. On 30 December 1928, Shang Zhen appealed to the Nationalist Government and proposed (1) that Chinese and foreign people should not excavate archaeological sites arbitrarily i.e., without the permission of the provincial government, and (2) that the central government should enact relevant preservation laws as soon as possible. These recommendations were positively received but would require some time before being enacted into clear policies.

The second incident occurred during the first official excavation, in 1928, of the Yin Xu site (Anyang, Henan province), the capital of the late Shang Dynasty (3,300 bp [kya]). Discovered in 1899, the site had acquired some fame as being the first documentedcapital site of Chinese history, which yielded numerous oracle bones as well as scapulae bearing inscriptions in an ancient form of Chinese writing. In 1928, new excavations at theYin Xu site were undertaken by the archaeological section of the Institute of History and Philosophy, Central Academy of Sciences, under the supervision of $\mathrm{Li} \mathrm{Ji}$. This excavation was special in many regards. For the first time, Chinese archaeologists conducted the excavations, and set the methodological foundations of what would become modern Chinese archaeology. At the same time the discovery of a royal palace and of several royal tombs revealed the importance of the site in the Chinese cultural landscape. Despite suchpromising start, however, tensions relating to the ownership of cultural relics emerged between the local, provincial and central governments. Indeed, on 8 October 1929, the Henan Provincial Government was made aware that the 
Institute of History and Languageof the Central Academy of Sciences had transported objects from the Yin Xu site from Anyang, Henan, to Beijing (formerly known as Peiping) without consent from the local authorities. In fierce reaction, He Rizhang, then director of the Henan Library and National Museum (the predecessor of the current Henan Museum), decided to lead a team of local workers and conduct the excavation of Yin Xu, while obstructing the personnel of the Institute of History and Philosophy from pursuing their work at the site. Frictions betweenthe two sides lasted for nearly 3 months. Although the dispute was resolved by agreeing that new finds from Yin Xu would be curated at the Henan Library and National Museum, the dispute had serious effects on the social landscape. Indeed, the involvement of local workers by He Rizhang raised the public awareness on the necessity to preserve local cultural heritage. In parallel, it also empowered local groups to challenge decisions from the central government that would deprive them from easily accessing the archaeologicaldiscoveries found at their localities. In a sense, this incident constituted an act of resistance to the centralisation of modern archaeological research in China, and casted suspicions towards the role of modern archaeology in the emergence of a nationalist narrative and the legitimation of a governing body.

Although seriously challenging the authority of the Nationalist government, the Yin Xudispute nevertheless highlighted the need to promptly formulate laws and regulations that would clarify the role of the State and its legitimacy when it comes to the protection of cultural relics. Less than a year after the Yin Xu dispute, the Nanjing Nationalist Government enacted the Antiquities Conservation Law of 2 June $^{\text {nd }}$, 1930. In accordance with Shang Zhen's appeal and in reaction to the previous year's turmoil in Henan, this firststatutory law aimed to 1) avoid the dissemination of archaeological relics abroad and 2) legitimate the Nationalist government as the protector of Chinese archaeological heritage. According to this Law, all ancient relics buried or exposed belong to State, and, consequently, the responsibility to protect historical sites and relics related to history, culture and art is incumbent to the State. Through this claim of ownership, the NationalistGovernment moved Chinese archaeological heritage from the private to the public sphere, and therefore laid down a clear legal foundation on which future principles of archaeological heritage protection and exhibition could rest. Interestingly, the Law itself gained widespread recognition and its core principle on 'State ownership' remains in effect to this day. In addition to moving the archaeological heritage from the private to the public sphere, the Antiquities Conservation Law also appointed state-funded local Museums, often referred to as Historical Museums, as institutions responsible for the curation and conservation of the archaeological relics and remains. Although this provision was likelya mean to avoid tensions between the local and central administrative bodies akin to what had happened for the Yin Xu relics, the practice of transferring archaeological relics to local Museums had already started earlier. Indeed, the outcome of another dispute taking place in the early 1920s did set a precedent on how to deal with archaeological relics..$^{10}$ In August 1923, a land owner, Li Rui, undertook a project to drill a well on one of his parcels in the Xinzheng County, Zhengzhou City, Henan Province. While doing so, he fortuitously unearthed artefacts from the Zheng State (2.8-2.3 kya), a vassal state of the Zhou Dynasty. The site in question, Li Jialou, gained fame and prestige as it yielded archaeological remains related to the Spring and Autumn Period of the Eastern Zhou Period as well as the tomb of the seventh emperor of the Zheng State. Questions of ownership arose from the very discovery of the site. Li Rui believed he was the sole and rightful owner of the relics he had unearthed on his private property. However, this view was not shared by Jin Yun'e, an influential local military leader, who advocated thatartefacts relating to the antiquity of the Chinese civilisation belonged to the State and could not be owned by any individual. Li Rui was eventually instructed to handing over allarchaeological relics that had been found to the Henan Museum. By this turn of events, the artefacts discovered at the Li Jialou site became the founding collection of the Henan Museum.

From the dispute on the ownership of the Li Jialou archaeological relics and, moreover following the enactment of the first protectionist law by the Nationalist Government, the fate of Chinese archaeology and of Historical Museums became intertwined. As Su" points out, the 1920s and 1930s are the two decades during which the foundation oflocal Historical Museums boomed in China, a period that coincided with a surge of archaeological excavations across the country. This co-dependence has often been acknowledged in the literature. ${ }^{12}$ In essence, archaeological projects allowed researchto shed light on past activities and on the antiquity of Chinese civilisation while Historical Museums, as state-funded institutions, provided the resources, 
human, material and financial, necessary to carry out excavations and an infrastructure fit for the curation of archaeological material and the display of the knowledge acquired through these research projects. In short, Historical Museums became the 'safe keeper' of archaeological relics.

\section{Authenticity and Integrity: The Rise of Archaeological Site Museums}

The enactment of the Antiquities Conservation Law did send a strong message both domestically and abroad on the Chinese State's will to protect its archaeological heritage. Indeed, this first legislation provided clear regulations as to who could conduct archaeological excavations and how these campaigns should be implemented, in addition to proclaiming the State's ownership over any archaeological finds unearthed during these projects. However, it failed to address issues pertaining to the preservation of archaeological sites. Indeed, people paid very little attention to the places where the antiquities were discovered at the time. Archaeological sites discovered during the 1930s and 1940s were not subjected to planned conservation or management as this concept did not exist then in China. ${ }^{13}$ The lack of concern for the protection of the archaeological sites themselves is understandable from both the political and academic perspectives. Politically, the law was first and foremost a response to halt private hunts of valuable archaeological relics and to curb their distribution abroad. This was achieved through the claim of ownership and through the regulations pertaining to how archaeological work should be carried out. From an academic perspective, this lack of concern for the protection of archaeological sites is not unique to China. One of the core concepts borrowed from foreign academicians at the time relates to type fossils, i.e., artefacts characteristic of a given cultural and/or historical period. Recovery methods in these early research years focused mainly on these distinguishable objects while neglecting the context in which they were unearthed as well as the other archaeological remains found in association withthem. When discovering an object that did not carry any monetary value or was not considered fit for being displayed in a Historical Museum, e.g., faunal remains, pottery sherds that could not be refitted to a pot or vessel, etc., it was commonplace to discard it. Archaeological sites were often randomly backfilled or abandoned following the recoveryof valuable relics. When archaeological excavations were conducted in conjunction with an infrastructure project, the deposit would simply be destroyed. Interestingly, theoreticaldebates in the archaeological academic circles would transform the general perception on the value of archaeological sites.

Despite being relatively isolated from Western academic influences, converging theoretical discussions took place in the 1950s challenging the founding principles at the origin of archaeological knowledge. At this time, New Archaeology was emerging in the United States as an alternative to address the limitations of the culturehistorical programme, in essence an approach which consisted of describing and cataloguing artefacts in order to create historical timelines. ${ }^{14}$ Meanwhile in China, the deliberations centred on preoccupations relating to the role of archaeology in the creation of an authentic and historically sound national narrative. Timelines of valuable archaeological relics were indeed only providing a partial view on the variability in past material culture.Furthermore, this view was highly distorted from the emphasis given to the protectionof prestigious goods. In the decade following the foundation of the People's Republic, such focus on the elite became frowned upon. This context favoured a major shift in archaeological research objectives. To document better past human activities and societies, archaeologists started paying more attention on the contexts yielding archaeologicalrelics. ${ }^{15}$ Chinese archaeologists, therefore, mobilised a great deal of effort in order to limit the damage inherent to their investigations of archaeological sites, a destruction sometimes compared to a 'murder', while retrieving as much data as possible and recording their findings in detailed reports, a document akin to an 'autopsy report'. ${ }^{16}$

Discussions on authenticity and integrity did not only concern the methods through which archaeological heritage came to light. Early in this process, questions were raised as to how archaeological heritage was exhibited and how it could be improved. Although transferring archaeological relics to state-funded Historical Museums was undeniably beneficial for their protection, their display in Museum windows deprived the general public of contextual knowledge on the social and environmental settings within which these relics 
were historically put to use. The main disadvantage of such means of exhibition was that historical narrative about the antiquity of Chinese civilisation was transmitted in a closed, one-sided way. The lack of possible interaction between the public and the contextual information made this mode of transmission quite inefficient, and so, not fully understandable. ${ }^{17}$ It is in an attempt to find a solution to this dual problem, protecting archaeological remains and creating an exhibition setting in which the public could visually interact with the context of the archaeological finds, that a second mode of protection and exhibition emerged: Archaeological Site Museum.

The first Archaeological Site Museum built in China, the Banpo Site Museum, opened in1958. In 1953, the excavations at Banpo quickly prompted widespread interest and excitement for both its scale and its excellent state of preservation. The site is locatedeast of Xi'an City, Shaanxi province, in the Yellow River Valley, and covers a 50,000- $\mathrm{m}^{2}$ area, a fifth of which was carefully excavated between 1954 and 1957. Archaeological research at the site led to the discovery of 46 houses, more than 200 cellars, 6 pottery kilnsand 250 tombs. More than 18,000 artefacts were unearthed as well as a large collection of ecofacts including grains of millet and rapeseed. Owing to the nature of the architectural and archaeological remains, and the Marxist paradigm that was prevalent in Chinesearchaeology at the time, Banpo was interpreted as a typical matriarchal settlement of the Neolithic Yangshao Culture ( 6.7-5.6 kya). ${ }^{18}$ The excavations carried at Banpo were the first to yield a large-scale prehistoric settlement site in China. Consequently, the research drew a lot of attention from academics - more than 200 archaeologists took part in the excavations - and fascinated the general public. ${ }^{19}$ The excavation methods developedand implemented at the Banpo site - including, isolating and excavating coherent structural units, sifting sediments and preserving stratigraphic profiles at the site were quickly viewed as representing significant progresses and paved the way for the development of settlement archaeology in China. ${ }^{20}$ Thanks to a widespread media coverage, the Banpo site soon became a major attraction for domestic and foreign experts as well asfor leaders and distinguished guests visiting the Xi'an region.

The exceptional discoveries made during these campaigns encouraged the conceptualisation of an infrastructure fit for both the curation of the archaeological relics and thedisplay of major site components worthy of preservation. Such infrastructure took the form of an Archaeological Site Museum, which combined both characteristics typical of Historical Museums - i.e., curating and exhibiting archaeological relics while facilitating archaeological research and educating the general public - and novelties that set this mode of protection and exhibition of archaeological heritage apart from its predecessor. On the one hand, the discovery of the Banpo site had the effect of expanding the scope ofarchaeological heritage to include the archaeological site as well as the relics it yielded. Consequently, the main innovation provided by this new mode of exhibition consisted of showcasing portions of the site as objects on display. Although the archaeological relics unearthed during the excavations formed the bulk of the Archaeological Site Museum's collection, the main attraction remained the site itself. ${ }^{21}$ On the other hand, building an Archaeological Site Museum on the premises of the deposit itself provided an enhanced experience to the general public. Showcasing both archaeological relics and remains in close proximity allowed the visitors to immerse themselves in the surrounding environment and to better link the relics on display with the spatial organisation of the site. Such visual interaction constitutes a major improvement in bringing awareness of the sitespecific spatial and social organisation within which the archaeological relics were used and a striking contrast to the rows of cabinets typically seen in Historical Museums. However, in line with McManus's view, most in-situ protection and exhibition projects still focused on the monuments and other artefacts themselves rather than on the landscapes surrounding them. ${ }^{22}$

This mode of protection and exhibition of the archaeological heritage was truly innovative. Indeed, when the UNESCO was suggesting to consider the establishment of special Museums for sites and landscape features in December 1962, the Banpo SiteMuseum had already been founded for 4 years..$^{23}$ As of 1975, and moreover following the 'Reform and Opening' policy in 1978, market intervention initiatives and a surge in domestic demand for cultural tourism led to a substantial increase in new infrastructures aimed to protect and exhibit cultural products. The large number of Archaeological Site Museums founded in this period, e.g. Zhoukoudian 
Site Museum, Jinsha Site Museum, Hemudu Site Museum, Emperor Qinshihuang's Mausoleum Site Museum, etc., quickly became the front-runners amongst museum institutions in attracting an increasing number of tourists year after year, a trend that has not decelerated to this day. For instance, visits at the Emperor Qinshihuang's Mausoleum Site Museum increased from

4.52 million persons in 2012 to 6.85 million in 2017. Despite this success, a major limitationremains that not all the archaeological sites can be transformed into museums. Aside fromthe evident financial burden related to building such large-scale infrastructure, manyarchaeological sites simply do not have 'displayable' structures and objects that would be considered attractive to the general public. To deal with these sites, a logic based on their classification along a tier-levelled scale akin to the one used for the relics themselves became the norm. Consequently, small archaeological sites are often not preserved after salvage excavation, and only large archaeological sites considered valuable for reinforcingthe national narrative celebrating the antiquity and ingenuity of Chinese civilisation enjoyed an in-situ preservation. ${ }^{24}$ Although preoccupations about authenticity and integrity were partly resolved with the introduction of Archaeological Site Museums, Historical Museums did not necessarily become obsolete. Far from it, their presence in the cultural landscape complemented that of Archaeological Site Museums.

\section{New Consumption Trends and the Landscape of Archaeological Site Parks}

China's opening to the globalised market economy at the end of the $20^{\text {th }}$ century had profound effects on archaeological heritage protection initiatives. In order to maintain its global competitiveness, economic priorities and massive investments shifted towards the maintenance and creation of infrastructures. The resulting fast urbanisation obviously became a threat to archaeological sites found on land with high development potential. To prevent destruction of valuable archaeological heritage, the State Council had instructed in its 1997 Notice on Strengthening and Improving the Work of Cultural Relics that 'the protection of ancient sites, especially large-scale sites, should be incorporated into local urban and rural construction and land-use planning.' Within this context, conflicting economic, cultural, and social priorities generated tensions amongst stakeholders and redefined the role cultural heritage in general, and archaeological heritage in particular, in this national development. Rapidly, a growing awareness emerged thatculture can foster and fuel economic development, particularly in developing countries, ${ }^{25}$ by turning evidence from the past into a marketable commodity, and therefore creating an accessible and attractive touristic attraction that contributes in its own ways to reinforce the national narrative. ${ }^{26}$ Increased globalisation punctuated by significant market fluctuations as well as rapid societal changes materialised in a thirst fortouristic consumption, both at home and abroad, and for technological innovations forced urban planners and heritage management professionals alike to consider new approaches to archaeological site conservation and management. ${ }^{27}$ Interestingly, the emerging solution, the Archaeological Site Park, would address McManus' critical viewon Archaeological Site Museum ${ }^{28}$ by anchoring the displayed archaeological heritagewithin a carefully conceptualised landscape.

Archaeological Site Parks refer to premises designed for leisure activities and thatfeature, as main touristic attraction, a major archaeological landmark protected at the national level owing to its high historical, cultural, and/or academic value. These landmarks include ancient settlements, cities, towns, temples, caves, kilns, engineering works, mausoleums and cemeteries, all of which can neither be demolished nor removed without the formal approval of the State Administration of Cultural Heritage (SACH). When present in the landscape, urban planning evolves around the archaeological features in order for the Archaeological Site Park to become a central focus for local social life. Consequently, the creation of Archaeological Site Parks provides a means for the protection of great archaeological sites and a tool to strengthen the local and national touristic economy. In December 2009, the SACH issued the 'Measures for the Management of National Archaeological Site Park (Trial Implementation)', which allowed for the construction of National Archaeological Site Parks to be part of the national urban planning strategy. In October 2010, this administrative body announced the first batch of 12 National Archaeological Site Parks, including, amongst other sites, the Yuanmingyuan Park, the Yin Xu Site Park, the Emperor Qinshihuang's Mausoleum Site Park, and theZhoukoudian Site Park. In June 
2011, the directors of these 12 archaeological parks gathered in Xi'an to establish the National Archaeological Site Park alliance. During this meeting, they issued the Declaration of National Archaeological Park Alliance, which advocate for the harmonious coexistence of cultural heritage with people, city and nature.In December 2013 and December 2017, the second and third batches of National Archaeological Site Parks were officially announced, both batches including 12 majorsites each. The protection of these 36 large-scale archaeological sites and their inclusion inthe urban planning through the design of National Archaeological Site Parks brought substantial economic benefits to local communities, such as offering employment, boosting revenue from touristic activities, improving environmental quality, and increasingland value. ${ }^{29}$

In addition to providing a solution for the issues related to archaeological heritage protection in a context of fast urban development, Archaeological Site Parks are meant to meet the needs of entertainment associated with mass cultural tourism. In today's global tourism industry, archaeological heritage becomes a marketable commodity. As such, archaeological remains and relics are converted into objects that reify narratives celebrating the antiquity and ingenuity of Chinese civilisation. In other words, heritage tourism contributes to the economic diversification and vitality both in urban and rural areas while participating in the creation and promotion of a national historical narrative and a sense of collective identity. ${ }^{30} \mathrm{In}$ this context, Archaeological Site Parks became a prominent tourist attraction that celebrates the social and cultural origins of Chinese society. Despite often being built around an Archaeological Site Museum, orat least including an exhibition and interpretation centre, the focus of ArchaeologicalSite Parks is not limited to the protection and exhibition of archaeological remains and relics. Central to this protection and exhibition model is the landscapes in which they are part of. This model is an innovative way of showcasing vast archaeological sites containing a number of monuments and using components of the environment as interpretative backdrop to somehow reinvent and/or emphasise the integrity of the archaeological remains. ${ }^{31}$ To convey this aura of integrity, some Archaeological Site Parks offer visitors with re-enactments of daily activities, prototypes or restorations of ancient monuments and structures, etc. These tools serve to stimulate the public senses through multiple interactions and to provide the audience with a pleasant and memorable experience.

Given its link to urban or territorial planning, Archaeological Site Park projects naturallybring together decision-makers and stakeholders from diverse horizons and with competing interests. If managed appropriately, they can play a stimulating role in thelocal economic development, ${ }^{32}$ and can have profound social, environmental impacts. From an environmental perspective, an Archaeological Site Park constitutes a protective measure not only for the great site or the monument it contains but also for the surrounding landscape which becomes subject to strict land-use regulations. The Lu Kingdom Archaeological Site Park development project in Qufu illustrates well this aspect.Located $130 \mathrm{~km}$ south of Jinan, the capital city of the Shandong province, Qufu is a small city best known as the hometown of Confucius. It contains a number of palaces, temples, and cemeteries, some of which have been listed as UNESCO world heritage sites for over 25 years, e.g., the Temple and the Cemetery of Confucius, the Kong Family Mansion, etc. During the Western Zhou and Eastern Zhou Dynasties ( 1.05-0.26 kya), Qufu served as the capital city of the Lu State, a kingdom perceived as a founder of modern Chinese civilisation. Nowadays, archaeological remnants of the city can be found over a $\sim 10.5 \mathrm{~km}^{2}$ area which is primarily used for agricultural activities. In December 2013, the land encompassing the archaeological remains was selected to be included in the second batch of National Archaeological Site Parks which led to the development of an urbanisation plan. The construction of the park is expected to last for 20 years, with a total investment hovering around 10 billion yuan ( 1.5 billion US\$). Such massive influx of capita in a rural area is bound to drastically transform the local economy. Indeed, individuals whose income depends on their access to the now-protected land had to permanently seek new source of revenue elsewhere, often from the employment opportunities offered during the construction period, and from the touristic-related services following the inauguration of the park. In creating a place that integrates education, scientific research, sightseeing, and leisure activities while protecting the surrounding environment, the Lu Kingdom Archaeological Site Park project is nonetheless cited asa model of harmonious urban development, i.e., a project that improves the resident's living conditions by updating the infrastructures, 
expanding the public cultural space and diversifying the local economy, protecting the archaeological heritage and exhibiting it,as well as increasing the prestige of the locality.

The creation of the Daming Palace Archaeological Site Park provides a contrasting example of the effects this type of project can have on the social fabric. Located in the citycentre of Xi'an, Shaanxi Province, the Daming Palace served as the imperial court and political centre for more than 220 years during the Tang Dynasty. In order to reconstruct the gate, courts, and halls which originally covered 350 hectares of land, more than 25,000 houses and stores were demolished which resulted in the dismantlement of the community, with the relocation of more than 100,000 inhabitants to various areas of the city. ${ }^{33}$ The case of the Daming Palace highlights how archaeological heritage protection, urban development, and local community's interests can often be disconnected from one another and can be very difficult to integrate. The complex web of relationships linking decision-makers with distinct, if not conflicting, goals forces parties to negotiate their respective powers and create alliances to achieve a 'consensual' outcome. However, the local population is often excluded from discussion on Chinese cultural heritage protection. Consequently, the lack of knowledge on the value of the archaeological remains found in their backyard and a misunderstanding of why they should, and how they can, participate in protection initiatives sometimes nurture a sentiment of discontent amongst less influential groups. ${ }^{34}$ Despite being an innovative solution to satisfy the demand for new cultural attractions while benefiting the local economic development strategy, Archaeological Site Parks also raise two major dilemmas. The first relates to the selection of sites and monuments eligible for such development. Given the primary mission of the heritage sector, thesites and monuments targeted are limited to those that can help promote Chinese traditional culture, reinforce a national sense of collective consciousness and identity, and elevate China's notoriety in the international cultural management arena. Unfortunately, such criteria preclude other sites from similar protection initiatives becausethey are either considered 'less attractive' or they 'hardly' fit in the national historical narrative. The second dilemma relates to the very nature of this narrative. Archaeological Site Parks are meant to be a blend of cultural nationalism and economic development whilst remaining attractive for a public savvy of new experiences. As such, the archaeological heritage it is supposed to protect also becomes a commodity. Such commodification of cultural heritage frequently results in the implementation of recreational solutions that lack historical accuracy.

\section{Conclusion}

The review presented thus far highlights the socio-historical context which gave rise to anawareness of the value of archaeological heritage in China. We identify three stages in thedevelopment and implementation of the ensuing archaeological heritage protection and exhibition initiatives, Historical Museums, Archaeological Site Museums, and Archaeological Site Parks. Briefly, Historical Museums appeared in the Chinese heritage management landscape as a means to ensure that valuable archaeological relics would remain within China. This corresponds to the time when the Chinese state proclaimed its ownership over archaeological relics, therefore moving them from the private to thepublic property. It also resulted in state-funded Historical Museums to naturally become the safe keepers of this heritage type while providing the general public with a space where the relics could be exhibited.

The second stage occurred following the discovery of the Banpo site. The excavation ofexceptionally wellpreserved structures encouraged the conception of Archaeological SiteMuseums, an institution where both archaeological relics and portions of the site could bedisplayed. The introduction of this new mode of protection and exhibition had two major consequences. First, it expanded the notion of archaeological heritage to include not onlythe relics but the remains as well. Second, it offered an opportunity for the general public to immerse itself in the environment by linking the relics put into display with the spatial organisation of the site.

The third stage constitutes a response to the rapid urbanisation, the influx in global tourism and economic priorities of the $21^{\text {st }}$ century. In this context, archaeological management of sites valuable to the promotion of a national narrative is integrated inthe urban or territorial planning. The resulting Archaeological Site Parks are proclaimed asexamples of a harmonious coexistence between cultural heritage, local residents, city, and 
nature. This mode of protection and exhibition is generally expected to bring substantial, lasting economic benefits to local community, to provide the general public witha premise fit for carrying out cultural and leisure activities, and to protect, in addition to the archaeological sites and monuments, the landscape that surrounds them.

Although they appeared successively, in part to palliate limitations from the previous mode of archaeological heritage management, the three types of institutions nowadays co-exist and complement each other in the Chinese cultural and touristic landscape. This complementarity has a lot to do with the classification of archaeological remains and relics into a hierarchical system of value in China. In this context, Archaeological Site Museums are mainly restricted to the protection of extremely well-preserved sites while Archaeological Site Parks are meant to showcase sites that are instrumental in reifying narratives that celebrate the antiquity and ingenuity of Chinese civilisation. Nonetheless, their co-existence raises challenges as to how the boundaries between them should be defined especially when conflicting interests amongst stakeholders come into play.

While Historical Museums did act as safe keepers of archaeological relics for mostof the $20^{\text {th }}$ century, recent signs show that this trend has somewhat been hindered.In the early days, most Museums had their own archaeological department which carried out archaeological excavations. The unearthed archaeological relics were then directly transferred to the Museums. However, since 1980s, these departments gradually became independent from museums, a trend that participated in the establishment of Provincial Archaeological Research Institutes. Likewise, major municipalities also set up teams and institutes responsible for surveying and excavating archaeological sites within their jurisdiction. Although the law clearly stipulates that excavated archaeological relics should be handed over to designated Museums in due time, these regulations have not always been fully implemented. By building their own storehouses and accumulating their own collections rather than handing them over, these institutions effectively limit the expansion of Museums' collections. These institutions may indeed protect China's archaeological heritage but they generally do little in making it accessible to the general public.

Aside from not being able to renew their collections available for display, Historical Museums likewise face an economic challenge owing to their status as non-profit organizations. Despite the growing domestic appetite for cultural attractions by an increasingly informed, cosmopolitan, and consumption-oriented public, ${ }^{35}$ Historical Museums must compete with more 'marketable institutions' to find the funds required to carry out their activities. Meanwhile, local authorities must negotiate between protecting the archaeological heritage and pursuing a fast-paced urban development that can yield notable economic advantages. At this game, Archaeological Site Museums and Parks definitely have the upper hand in attracting capital investments and much of the outcome rests on the site notoriety.

Evidently, archaeological heritage management differs from other forms of heritage management. Its foremost priority remains the preservation of archaeological sites and the material culture they yielded. As such, maintaining the integrity of both archaeological sites and relics is primordial for future scientific research. ${ }^{36}$ However, and most importantly, our review also underlines the shifting roles archaeological heritage played in China over the years. In the first two stages, growing awareness ofthe value this nonrenewable resource carries led to the realization that archaeological heritage must be protected. The developments in heritage management at the time aimed to fulfil this task, first by targeting valuable movable material culture, andthen by extending this provision to other artefactual and structural components of an archaeological deposit. In the final stage, however, archaeological heritage protection, and moreover exhibition initiatives, started to serve a new purpose. Their mission now includes promoting traditional Chinese values, contributing to building a national sense of consciousness and identity, and participating in the global positioning of China. It is in a context of increasing wealth, social changes, and constant technological innovations that archaeological heritage morphed into a marketable commodity effectively used to create a national historical narrative. Interestingly, this seismic shift in perspective revives the issue on archaeological heritage authenticity and integrity, and it accentuates the fact that these concepts depend more on social processes and local cultural practices rather than on objective criteria. ${ }^{37}$ Debates 
relating to the authenticity of a reconstructed past, the struggles between heritage preservation and urban development, the difficulty to finda balance between culture and consumption, and the responsibility of expert researchers towards their communities occupy a central place in Western academic discourse. ${ }^{38}$ These preoccupations are not region-specific and the solutions implemented elsewhere could very well inspire the forthcoming development strategy in China. Therefore, we argue that the success of future archaeological heritage protection and exhibition initiatives will heavily rest on a prior understanding by decisionmakers of the origin and transformation through recent history, and on their capacityto innovate, and/or adapt solutions implemented in other countries, to meet the demands of an increasingly critical public.

\section{Notes}

1. ICOMOS, The $9^{\text {th }}$ General Assembly Charter, Article 1.

2. Fraser, Lawrence and Haber, Time, Science and Society, 227; Clunas, Superfluous Things, 95; andTrigger, History of Archaeological Thought, 74-5.

3. Bollo and Zhang, "Policy Impact Public Museums," 26.

4. e.g., Adams, "Underwater archaeology Chinese agenda," Chapter 14.

5. e.g., Li, Issues on Archaeological Heritage; Zhao and Zhang, "Inspirations from Lausanne Charter"; Cui, "Archaeological Heritage Classification"; Jiao, Impact of Relics Activation; andLi, Social Values and Industrialisation.

6. He, "Illicit Excavation Contemporary China," Chapter 3.

7. See note 2 above.

8. Maus Stephen, "Domestic Archaeological Heritage Management."

9. Huo, "Origin Law Preservation Antiquities"; and Maus Stephen, "Domestic ArchaeologicalHeritage Management."

10. Xu, Famous Mountains.

11. Su, "Chinese Museum New Century," 404-11.

12. Ceng, "Museum and Archaeological Work," 309-13; Su, Make Archaeological Career; and Xu, Famous Mountains.

13. Lu, "Issues on the Management."

14. Trigger, History of Archaeological Thought, Chapter 6.

15. See note 6 above.

16. Cao, "Thoughts on Archaeological Excavations," 51-5.

17. Lowenthal, The Past is a Foreign Country; and Lu, Museums in China.

18. For a critical review of this interpretation, see Li, The Chinese Neolithic, Chapters 1 and 4.

19. Wang and Wang, Xi'an Banpo Museum.

20. Wei, "Building Banpo Museum," 394-7.

21. Huang, "Archaeological Work and Site Museums," 13-8.

22. McManus, "Archaeological Parks," 57-9.

23. Su, "The Banpo Site Museum," 292-5.

24. See note 13 above.

25. Loulanski, "Cultural Heritage in Socio-economic Development"; and Nhamo andKatsamudanga, "Heritage Preservation and Community Development."

26. Shepherd and Larry, Heritage Management, Tourism and Governance.

27. Williams, "Conservation and Management: 20-years Perspective."

28. McManus, "Archaeological Parks," 57-9. Note: The author argues that most in-situ protection and exhibition projects still focus on the monuments and other archaeological relics and remains rather than on the landscape that surrounds them.

29. Levin et al., "An Evolution in Values," 19-24.

30. Dicks, Culture on Display; Gentry, "History, Heritage and Localism"; and Salazar and Zhu, "Heritage and Tourism," Chapter 11.

31. Papageorgiou, "Unification of Archaeological Sites."

32. Comer, Tourism at Petra; Qian, "Challenges in Archaeological Tourism"; and Thomas and Langlitz, "Archaeotourism, Archaeological Site Preservation," Chapter 7.

33. Zhu, "Uses of the Past."

34. Maags and Scensson, Chinese Heritage in the Making; Smith and Waterton, Heritage,Communities and Archaeology; and Hodder, "Social Thought and Commentary."

35. Varutti, Museums in China, 241. 
36. Comer, Tourism at Petra.

37. Zhu, "Cultural Effects of Authenticity."

38. e.g., Goulding, "Commodification of the Past"; Chhabra, "Positioning Museum Authenticity Continuum"; Nitzky, "Ecomuseum Development in China"; Brida, Dalle Nogare, and Scuderi, "Frequency of Museum Attendance"; and Alivizatou, Intangible Heritage and the Museum.

\section{Disclosure Statement}

The funders had no role in the study design, decision to publish, or preparation of this manuscript. The authors declare no conflict of interest.

\section{Funding}

LD acknowledges the financial support of the China Postdoctoral Sciences Foundation through its China/Shandong University International Postdoctoral Exchange Program. PACEA (CNRS UMR5199) is a Partner team of the Labex LaScArBxANR (ANR-10-LABX-52).

\section{Notes on contributors}

Zhao Huijun is a PhD candidate in Cultural Heritage Studies at the Institute of Cultural Heritage of Shandong University. She has an interdisciplinary background in archaeology, museum studies and cultural heritage studies. She is interested in how political and social contexts shaped the development of cultural heritage and museums in modern Chinese history.

Luc Doyon is a researcher in archaeology at the Institute of Cultural Heritage of Shandong Universityand at the CNRS UMR5199 PACEA, University of Bordeaux. He specialised in the study of Late Pleistocene and Holocene bone and shell technologies from Europe and East Asia. He also has an interest in initiatives that target the engagement of the public interest towards archaeological sciences and discoveries.

\section{Bibliography}

Adams, J. "The Role of Underwater Archaeology in Framing and Facilitating the Chinese NationalStrategic Agenda." In Cultural Heritage Politics in China, edited by T. Blumenfield and

H. Silvermann, 261-282. New York: Springer, 2013.

Alivizatou, M. Intangible Heritage and the Museum: New Perspectives on Cultural Preservations. Oxon:Routledge, 2016.

Bollo, S., and Y. Zhang. "Policy and Impact of Public Museums in China: Exploring New Trends andChallenges." Museum International 69, no. 3-4 (2017): 26-37. doi:10.1111/muse.12170.

Brida, J. G., C. Dalle Nogare, and R. Scuderi. "Frequency of Museum Attendance: Motivation Matters." Journal of Cultural Economics 40, no. 3 (2015): 261-283. doi:10.1007/s10824-015-9254-5.

Cao, B. "New Thoughts on Archaeological Excavations." Journal of National Museum of China 1995, no. 1 (1995): 51-55.

Ceng, Z. "A Report on Museum and Archaeological Work." In Ceng Zhaoyu Corpus:Museum Volume, edited by G. Liang, 309313. Beijing: Cultural Relics Press, 2009.

Chhabra, D. "Positioning Museums on an Authenticity Continuum." Annals of Tourism Research 35, no. 2 (2008): $427-447$. doi:10.1016/j.annals.2007.12.001.

Clunas, C. Superfluous Things: Material Culture and Social Status in Early Modern China. Honolulu: University of Hawaii Press, 2004.

Comer, D. Tourism and Archaeological Heritage Management at Petra: Driver to Development or Destruction? New York: Springer, 2012.

Cui, S. "The Concept of Archaeological Heritage and Its Classification." China Cultural Relics News, May 8, 2015.

Dicks, B. Culture on Display: The Production of Contemporary Visitability. Maidenhead: Open University Press, 2003.

Fraser, J. T., N. Lawrence, and F. C. Haber. Time, Science and Society in China and the West. The Study ofTime. Amherst: University of Massachusetts Press, 1986.

Gentry, K. “History, Heritage and Localism." Policy Studies 34, no. 5-6 (2013): 508-522. doi:10.1080/ 01442872.2013.864083.

Goulding, C. "The Commodification of the Past, Postmodern Pastiche, and the Search for Authentic Experiences at Contemporary Heritage Attractions." European Journal of Marketing 34, no. 7 (2000): 835-853. 
He, S. "Illicit Excavation in Contemporary China." In Trade in Illicit Antiquities: The Destruction of the World's Archaeological Heritage, edited by N. Brodie, J. Doole, and C. Renfrew, 19-24. Cambridge: McDonald Institute for Archaeological Research, 2001.

Hodder, I. "Social Thought and Commentary: Archaeological Reflexivity and the 'Local' Voice." Anthropological Quarterly 76, no. 1 (2003): 55-69. doi:10.1353/anq.2003.0010.

Huang, Y. "The Relationship between Archaeological Work and Archaeological Site Museums." Southeast Culture 2015, no. 2 (2015): 13-18.

Huo, Y. "An Analysis of the Origin and End of the Establishment of the Law on the Preservation ofAntiquities." Archives 2014, no. 4 (2014): 51-54.

ICOMOS (International Council on Monuments and Sites). 1990. "The 1990 Lausanne Charter for theProtection and Management of the Archaeological Heritage." Archaeological-Heritage.pdf

Jiao, X. "Discussion of Impact of Relics Activation on Protection and Utilization Approaches: Take theOld Summer Palace as an Example." ISPRS Annals of the Photogrammetry, Remote Sensing and Spatial Information Sciences, no. II-5/W3 (2015): 351-356. doi:2015.

Levin, J., J. Fan, J. Zheng, and Z. Lu. "An Evolution in Values: A Discussion about Cultural Heritage Conservation in China." Conservation Perspectives, The GCI Newsletter 2016, no. 1 (2016): 19-24.

Li, J. "A Discussion on the Social Values and Industrialization of Archaeological Heritage." Southeast Culture 2016, no. 2 (2016): 13-18.

Li, L. The Chinese Neolithic: Trajectories to Early States. Cambridge: Cambridge University Press, 2004.

Li, X. "Several Issues on the Research and Protection of Archaeological Heritage." HuaXia Archaeology 1993, no. 4 (1993): 101-108.

Loulanski, T. "Cultural Heritage in Socio-Economic Development: Local and Global Perspectives." Environments: A Journal of Interdisciplinary Studies 34, no. 2 (2006): 51-69.

Lowenthal, D. The past Is a Foreign Country. Cambridge: Cambridge University Press, 1985.

Lu, T. L.-D. "Some Issues on the Management of Archaeological Sites in Mainland China." Conservation and Management of Archaeological Sites 10, no. 4 (2008): 353-366. doi:10.1179/ 135050308 X 12513845914543.

Lu, T. L.-D. Museums in China: Power, Politics and Identities. New York: Routledge, 2014.

Maags, C., and M. Svensson. Chinese Heritage in the Making: Experiences, Negotiations and Contestations. Amsterdam: Amsterdam University Press, 2018.

Maus Stephen, A. K. "China: Domestic Archaeological Heritage Management Law." In Encyclopedia ofGlobal Archaeology, edited by C. Smith, 1-8. New York: Springer, 2014.

McManus, P. M. "Archaeological Parks: What Are They?" Archaeology International, no. 3 (1999): 57-59. doi:10.5334/ai.3017.

Nhamo, A., and S. Katsamudanga. "Linking Heritage Preservation and Community Development: An Assessment of Grassroots Heritage Based Projects as Vehicles for Socio-Economic Development and Sustainable Heritage Preservation in Zimbabwe." Conservation and Management of Archaeological Sites 21, no. 1 (2019): 25-44. doi:10.1080/13505033.2019.1596518.

Nitzky, W. "Mediating Heritage Preservation and Rural Development: Ecomuseum Development in China." Urban Anthropology and Studies of Cultural Systems and World Economic Development 41, no. 2 (2012): 367-417.

Papageorgiou, L. "The Unification of Archaeological Sites of Athens: The Birth of an Archaeological Park?" Conservation and Management of Archaeological Sites 4, no. 3 (2000): 176-184. doi:10.1179/ 135050300793138291.

Qian, G. "Challenges in Archaeological Tourism in China." International Journal of Historical Archaeology 20, no. 2 (2016): 422-436. doi:10.1007/s10761-016-0333-x.

Salazar, N., and Y. Zhu. "Heritage and Tourism." In Global Heritage: A Reader, edited by L. Meskell, 240-258. Hoboken, NJ: John Wiley \& Sons, 2015.

Shepherd, R. J., and Y. Larry. Heritage Management, Tourism and Governance in China. New York: Springer, 2013.

Smith, L., and E. Waterton. Heritage, Communities and Archaeology. London: Bristol Classical Press, 2009.

Su, B. "How to Make the Archaeological Work People's Career." In Su Bingqi corpus (2), edited by B. Su, 89-95. Beijing: Cultural Relics Press, 2009.

Su, D. "The Banpo Site Museum Should Be Given a Higher Historical Evaluation." In Reflections on Museums - Selected Essays of Su Donghai, edited by D. Su, 292-295. Beijing: Cultural Relics Press, 1998.

Su, D. "View the Chinese Museum from the Height of the New Century." In Reflections on Museums - Selected Essays of Su Donghai (Volume 2), edited by D. Su, 404-411. Beijing: Cultural Relics Press, 2006.

Thomas, B., and M. Langlitz. "Archaeotourism, Archaeological Site Preservation, and Local Communities." In Feasible Management of Archaeological Heritage Sites Open to Tourism, edited by D. C. Comer and A. Willems, 69-78. Cham: Springer, 2019.

Trigger, B. G. A History of Archaeological Thought: Second Edition. New York: Cambridge University Press, 2006.

Varutti, M. Museums in China: The Politics of Representation after Mao. Woodbridge: Boydell Press, 2016.

Wang, Y., and Z. Wang. Xi'an Banpo Museum. Xi'an: Sanqin Press, 2003. 
Wei, G. "On the Historical Significance and Social Value of Building Banpo Museum." Prehistoric Studies 1998, no. 8 (1998): 394-397.

Williams, T. "The Conservation and Management of Archaeological Sites: A Twenty-Year Perspective." Conservation Perspectives, The GCI Newsletter 33, no. 1 (2018): 5-9.

Xu, J. Undercurrent: Chinese Archaeological Tradition Outside Anyang Before 1949. Beijing: SciencePress, 2012.

Xu, J. Famous Mountains: The History of Early Chinese Museums as a History of Thoughts. Beijing:Science Press, 2017.

Zhao, Y., and J. Zhang. "Inspirations from Lausanne Charter to Planning Archaeological HeritageProtection: Site of Capital of Kingdom Lu, Qufu." East Archaeological 8 (2011): 102-109.

Zhu, Y. "Cultural Effects of Authenticity: Contested Heritage Practices in China." International Journalof Heritage Studies 21, no. 6 (2015): 594-608. doi:10.1080/13527258.2014.991935.

Zhu, Y. "Uses of the Past: Negotiating Heritage in Xi'an." International Journal of Heritage Studies 24, no. 2 (2017): $181-192$. doi:10.1080/13527258.2017.1347886. 